\title{
Foxp3 expression in breast cancer patient from Qatar: survival analysis
}

\author{
Mahmoud G Mohamed ${ }^{1,2}$, Hina Sarwath', Shaykha Alqahtani', Salha Bujjasoum², Imad Bin Mujeeb², \\ Mufeed Almesteri ${ }^{2}$, Hikmat Bugrein ${ }^{2}$, Prem Chandra ${ }^{2}$, Shahinaz Bedri ${ }^{{ }^{*}}$ \\ From Breast Cancer Immunotherapy Symposium (BRECIS), part of the Sidra Symposia Series, held in partner- \\ ship with the Society for Immunotherapy of Cancer \\ Doha, Qatar. 13-14 April 2015
}

In breast cancer, the presence of Foxp3 (Tregs) [1] within the tumor milieu has been a matter of debate. Some studies have determined that infiltration of Tregs was associated with poor survival, while others revealed no impact on survival, however this depends on their type, type of cells expressing Foxp3 and the density of the Tregs population [2].

The goal of our study was to quantify Foxp3 in breast cancer patients from Qatar and correlate with their survival.

\section{Methodology}

Expression of FoxP3 was studied in 132 FFPE samples with known clinico-pathological data by immunohistochemistry technique and quantified by modified $\mathrm{H}$-score system by pathologist. Results were analyzed via SPSS.

\section{Results}

Analysis was carried for 132 patients. Age at time of diagnosis was $49 \pm 10.4$ years. $76.2 \%$ of the patients showed positive expression of FoxP3. FoxP3 expression was not correlated with patient age or hormone receptors. Expression of Foxp3 positively correlate with better patient survival when compared to negative expression (94.1, 95\% CI 85.6 - 102.6 versus $83.6,95 \%$ CI 71.8 - 95.5, p 0.60).

\section{Conclusion}

FoxP3 is expressed on lymphocytes that are present in the tumor microenvironment regardless of breast cancer subtypes. Foxp3 is correlated with better survival.

\section{Authors' details}

${ }^{1}$ Research, Weill Cornell Medical College in Qatar, Doha, Qatar. ${ }^{2} \mathrm{Hamad}$

Medical Corporation, Doha, Qatar.

Published: 14 August 2015

\section{References}

1. Mackay C.R.: Dual personality of memory T cells. Nature 1999 , 401(6754):659-660.

2. Mahmoud S.M., Paish E.C., Powe D.G., Macmillan R.D., Lee A.H., Ellis I.O., Green A.R.: An evaluation of the clinical significance of FOXP3+ infiltrating cells in human breast cancer. Breast Cancer Research and Treatment 2011b, 127(1):99-108.

doi:10.1186/2051-1426-3-S1-02

Cite this article as: Mohamed et al:. Foxp3 expression in breast cancer patient from Qatar: survival analysis. Journal for ImmunoTherapy of Cancer 2015 3(Suppl 1):O2.
Submit your next manuscript to BioMed Central and take full advantage of:

- Convenient online submission

- Thorough peer review

- No space constraints or color figure charges

- Immediate publication on acceptance

- Inclusion in PubMed, CAS, Scopus and Google Scholar

- Research which is freely available for redistribution

Submit your manuscript at www.biomedcentral.com/submit
() Biomed Central
C Biomed Central

C 2015 Mohamed et al. This is an Open Access article distributed under the terms of the Creative Commons Attribution License (http://creativecommons.org/licenses/by/4.0), which permits unrestricted use, distribution, and reproduction in any medium, provided the original work is properly cited. The Creative Commons Public Domain Dedication waiver (http://creativecommons.org/ publicdomain/zero/1.0/) applies to the data made available in this article, unless otherwise stated. 